\title{
Polymorphisms in the bone morphogenetic protein 15 gene and their effect on sperm quality traits in Chinese Holstein bulls
}

\author{
L.P. Sun ${ }^{1}$, Y.P. Song ${ }^{1}$, Q.Z. Du ${ }^{1}$, L.W. Song ${ }^{2}$, Y.Z. Tian ${ }^{3}$, S.L. Zhang ${ }^{4}$, \\ G.H. Hua ${ }^{1}$ and L.G. Yang ${ }^{1}$
}

${ }^{1}$ Key Laboratory of Agricultural Animal Genetics, Breeding and Reproduction, Ministry of Education, Huazhong Agricultural University, Hubei Wuhan, China ${ }^{2}$ Henan Province's Bureau of Animal Husbandry \& Veterinary Medicine, Zhengzhou, China

${ }^{3}$ Tianjin Dairy Cattle Development Center, Tianjin, China

${ }^{4}$ Beijing Dairy Center, Beijing, China

Corresponding author: L.G. Yang

E-mail: yangliguo2006@yahoo.com.cn

Genet. Mol. Res. 13 (1): 1805-1812 (2014)

Received December 13, 2012

Accepted August 16, 2013

Published March 17, 2014

DOI http://dx.doi.org/10.4238/2014.March.17.8

\begin{abstract}
Bone morphogenetic protein 15 (BMP-15) expression has been detected in the testis, but its roles in this organ has not been well elucidated. We evaluated polymorphisms of the BMP-15 gene by PCRSSCP and PCR-RFLP in 212 Chinese Holstein bulls, and investigated possible associations with sperm quality traits, including semen volume per ejaculate, sperm density, fresh sperm motility, thawed sperm motility, acrosome integrity rate, and abnormal sperm rate. A single nucleotide polymorphism (C5697T) in intron 1 of the $B M P-15$ gene was identified in these bulls. Age was found to have significant effects on both fresh sperm motility and abnormal sperm rate. A significant effect of genotype on fresh sperm motility was also observed. Least square analysis showed that CT genotype bulls had significantly lower
\end{abstract}


fresh sperm motility than CC or TT genotype bulls. In conclusion, $B M P-15$ should be considered as a potential genetic marker for sperm quality, based on its association with fresh sperm motility.

Key words: $B M P-15$; Polymorphism; Association; Sperm quality traits; Chinese Holstein bulls

\section{INTRODUCTION}

As is known to all, the main emphasis of genetic improvement in dairy cattle is placed on selection of good herd sires. Sperm quality is an important indicator of herd sire. It should go without saying that a good herd sire must have the characteristic of good sperm quality. Heritability values estimated for different sperm quality traits are of low-to-medium magnitudes (England et al., 2010; Wolf, 2010). The genetic parameters and the development of molecular biological techniques have led many researchers to use candidate gene studies to predict sperm quality traits in bulls (Yang et al., 2011; Sang et al., 2011; Sun et al., 2012). However, there have been few studies reporting on the bone morphogenetic protein 15 (BMP15) gene in bulls.

$B M P-15$ is a member of the transforming growth factor beta $(T G F \beta)$ superfamily. It is synthesized and secreted by oocytes and has critical roles in the regulation of fertility. Studies have shown that mutations in $B M P-15$ can cause both increased ovulation rate and infertility phenotypes in a dosage-sensitive manner (Galloway et al., 2000). Associations between mutations in the $B M P-15$ gene and reproductive performance have been extensively studied by previous researchers (Nicol et al., 2009; Barzegari et al., 2010). Mutations in the $B M P-15$ gene may also be involved in premature ovarian failure (Dixit et al., 2006; Laissue et al., 2006; Kovanci et al., 2007). However, $B M P-15$ expression patterns, signaling and function during spermatogenesis remain to be elucidated. Recently, expression and localization of $B M P-15$ in male testis and epididymis have been studied. Studies have shown that BMP-15 is stage-specifically localized in gonocytes and pachytene spermatocytes of the seminiferous epithelium (Nicholls et al., 2009). Expression of BMP-15 protein was first identified in the 3-day post-partum (dpp) rat testis, but absent in the 9-dpp testis and then present in the 18dpp testis and later time points. Expression of $B M P-15$ mRNA was only found in pachytene spermatocytes (Nicholls et al., 2009). The expression patterns of BMP-15 in the testis suggest that its proteins may potentially have distinct functions at defined points of spermatogenesis. BMP-15 null mice are normal and fertile (Yan et al., 2001). However, no data have been presented regarding testicular function (e.g., sperm count, maturation, mobility, or viability), tight junction function or the circulating concentrations of key hormones, including testosterone, follicle-stimulating hormone (FSH), and the inhibins. BMP-15 effects on any of these parameters could reduce male fertility.

To further elucidate the effect of $B M P-15$ on male reproduction, the aim of this study was first to determine the polymorphism of the $B M P-15$ gene by the polymerase chain reaction-restriction fragment length polymorphism (PCR-RFLP) method, and secondly to examine the relationship between $B M P-15$ gene polymorphisms and sperm quality traits in Chinese Holstein bulls. 


\section{MATERIAL AND METHODS}

\section{Samples and data collection}

All procedures involving animals were approved by the Animal Care and Use Committee of Huazhong Agricultural University. DNA samples were collected from a total of 212 Chinese Holstein bulls, including 35 obtained from the Henan Breeding Bull Co., Ltd., 45 bulls from the Beijing Dairy Center, 72 from the Shanghai Dairy Breeding Center, and 60 from the Tianjin Dairy Center. About 40 to 70 ejaculates (average of 65 ejaculates) were collected at intervals of 3-6 days from each bull aged 1-14 years, and repeated measurements of the sperm quality traits were available. The semen was collected using an artificial vagina. Immediately after collection, the ejaculates were stored at $37^{\circ} \mathrm{C}$ in a water bath to evaluate the fresh semen quality traits including semen volume per ejaculate $[\mathrm{VOL}(\mathrm{mL})]$, fresh sperm motility [FSM $(\%)]$ and sperm density [SD (x 108/mL)]. The fresh semen samples were then diluted with glycerol-egg yolk-citrate and made into frozen semen straws. After storage in liquid nitrogen for 5-7 days, three straws were randomly obtained from each ejaculate and thawed at $38^{\circ} \mathrm{C}$ for $20 \mathrm{~s}$, and immediately afterwards frozen semen quality traits were evaluated including thawed sperm motility [TSM (\%)], acrosome integrity rate [AIR (\%)] and abnormal sperm rate [ASR $(\%)$ ] with light microscopy according to the guidelines of the World Health Organization. Genomic DNA was extracted from the sperm using the standard phenol-chloroform extraction protocol with minor modification. Genomic DNA was diluted to $50 \mathrm{ng} / \mu \mathrm{L}$ according to its concentration and stored at $-20^{\circ} \mathrm{C}$ for subsequent analysis.

\section{Primers and PCR conditions}

To screen the potential SNPs, five pairs of primers were designed according to the bovine BMP-15 (Gene ID: 353351) DNA sequence. Primers were synthesized to amplify exon 1, part of intron 1 and exon 2 (Table 1).

The PCR volume was $20 \mu \mathrm{L}$, which included $10 \mu \mathrm{L}$ PCR Mastermix, $0.5 \mu \mathrm{L}$ of each primer, $1 \mu \mathrm{L}$ genomic DNA template, and $8 \mu \mathrm{L}$ ultrapure water. The PCR amplification conditions were optimized in a Gene Amp PCR System 9600 (Applied Biosystems, Foster City, CA, USA). The thermal program consisted of an initial denaturation $\left(94^{\circ} \mathrm{C}\right.$ for $\left.5 \mathrm{~min}\right)$ followed by 35 cycles of $40 \mathrm{~s}$ at $94^{\circ} \mathrm{C}, 30 \mathrm{~s}$ at annealing temperature (Table 1 ), and $30 \mathrm{~s}$ at $72^{\circ} \mathrm{C}$, and a final extension of $7 \mathrm{~min}$ at $72^{\circ} \mathrm{C}$. PCR products were electrophoretically detected on a $2.0 \%$ agarose gel $(5 \mathrm{~V} / \mathrm{cm})$ by ethidium bromide staining.

\begin{tabular}{|c|c|c|c|c|}
\hline & Primer sequence & Location & Product size (bp) & Annealing temperature $\left({ }^{\circ} \mathrm{C}\right)$ \\
\hline $\mathrm{B} 1$ & $\begin{array}{l}\text { F: 5'-GCAGCCCTCTATTGCCCACCT-3' } \\
\text { R: 5'-CAAGCCCAAGAAAACCACCCA-3' }\end{array}$ & Exon 1 and part intron 1 & 375 & 61.7 \\
\hline B2 & $\begin{array}{l}\text { F: 5'-ACTGGCTTGTGTGTCCTCTGGC-3' } \\
\text { R: 5'-GTGATTGGTTGGGCTTTTCTGG-3' }\end{array}$ & Intron 1 and part exon 2 & 436 & 61.5 \\
\hline B3 & $\begin{array}{l}\text { F: 5'-TACCGCCATCAACTTCACCT-3' } \\
\text { R: 5'-CCAGAACTCACGAACCTCACT-3' }\end{array}$ & Exon 2 & 255 & 69.5 \\
\hline B4 & $\begin{array}{l}\text { F: 5'-AAGAGGTAGTGAGGTTCGT-3' } \\
\text { R: 5'-GTAGTTTGGGGTATAGAGA-3' }\end{array}$ & Exon 2 & 328 & 49.0 \\
\hline B5 & $\begin{array}{l}\text { F: 5'-GTGTTCCCTCCACCCTTTT-3' } \\
\text { R: 5'-GGGCAATCATACCCTCATA-3' }\end{array}$ & Exon 2 & 290 & 60.0 \\
\hline
\end{tabular}




\section{Single-strand conformation polymorphism (SSCP) detection and sequencing}

Aliquots of $4 \mu \mathrm{L}$ PCR products were mixed with $12 \mu \mathrm{L}$ denaturing solution (95\% formamide, $25 \mathrm{mM}$ EDTA, $0.025 \%$ xylene cyanol and $0.025 \%$ bromophenol blue), heated for $10 \mathrm{~min}$ at $99^{\circ} \mathrm{C}$ and immediately chilled on ice. Finally, the denatured DNA was subjected to $10 \%$ polyacrylamide gel electrophoresis $(\mathrm{PAGE}$ ) (acrylamide:bisacrylamide $=29: 1$ ) in $1 \mathrm{X}$ Tris-borate EDTA (TBE) buffer at constant voltage (140 V) for 14 to $16 \mathrm{~h}$. The gel was stained with $0.2 \%$ silver nitrate, and finally, the PCR products with different SSCP patterns were sequenced in an ABI PRIZM 377 DNA sequencer in both directions to identify the SNPs.

\section{Genotyping}

To detect the polymorphism of $B M P-15$ in intron 1, the PCR products were digested with $M s p I$. The digestion reactions were performed by mixing $3 \mu \mathrm{L}$ PCR products with $4 \mathrm{U}$ restriction enzymes (MBI, China) and $1 \mu \mathrm{L}$ corresponding $10 \mathrm{X}$ reaction buffer. This was followed by incubation at $37^{\circ} \mathrm{C}$ overnight. Finally the digestion products were subjected to $8 \%$ PAGE (29:1 acrylamide:bisacrylamide) and then stained with $0.2 \%$ silver nitrate solution.

\section{Statistical analysis}

Allele and genotype frequencies of the studied SNPs were determined by direct counting. Effect of age, SNP genotypes and their interaction with the sperm quality traits VOL, SD, FSM, AIR, ASR, and TSM were analyzed by the general linear model (GLM) of the SAS 9.0 software. The significance of differences between genotypes was determined by the least-squares means method and compared by the Duncan multiple range test. Only factors that affected the records significantly $(\mathrm{P}<0.05)$ were fitted in the final statistical model shown as follows (Sun et al., 2012):

$$
\mathrm{y}_{\mathrm{ikj}}=\mu+\mathrm{G}_{\mathrm{i}}+\mathrm{A}_{\mathrm{k}}+\mathrm{P}_{\mathrm{j}}+\mathrm{e}_{\mathrm{ikj}}
$$

where $y_{i k j}$ is the sperm quality trait; $\mu$ is the overall population mean; $G_{i}$ is fixed effect of genotypes; $A_{k}$ is fixed effect of age [(1) 1-3 years; (2) 4-6 years; (3) over 7 years], $P_{j}$ is fixed effect of the origin of bull, and $e_{i k j}$ is random residual error.

\section{RESULTS}

\section{Polymorphisms of the bovine BMP-15 gene}

One mutation (C5697T) was identified at intron 1 of the BMP-15 gene, which forms an $M s p I$ endonuclease restriction site (primer B2). Therefore, the $M s p$ I digestion of amplified products generated three genotypes: 202, 117 and $117 \mathrm{bp}$ for the CC genotype, 319, 202, 117, $117 \mathrm{bp}$ for the CT genotype, and 319 and $117 \mathrm{bp}$ for the TT genotype (Figure 1). The genotypic frequency of the TT genotype was much higher than that of the CT genotype (Table 2). 


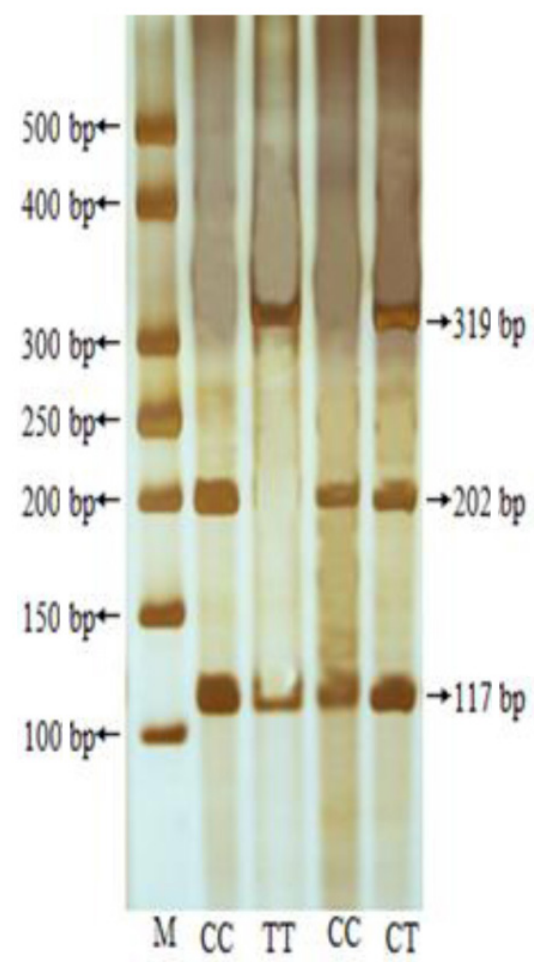

Figure 1. Representative genotyping profile of the BMP-15 gene at loci C5697T. Bands with 202, 117 and 117 bp for the CC genotype, 319, 202, 117, $117 \mathrm{bp}$ for the CT genotype, 319, $117 \mathrm{bp}$ for the TT genotype appeared at this locus. Lane $M=50$-bp DNA ladder marker (Omega).

Table 2. Allelic and genotypic frequencies for sequence polymorphisms in the BMP-15 gene in Chinese Holstein bulls.

\begin{tabular}{llccc}
\hline Locus & Genotype & Genotypic frequency & Allele & Allelic frequency \\
\hline C5697T & CC (84) & 0.398 & C & 0.408 \\
& CT (4) & 0.019 & T & 0.592 \\
\hline
\end{tabular}

Numbers of samples are cited in parentheses.

\section{Effect of age, genotype and their interaction on sperm quality traits in Chinese Holstein bulls}

Effect of age, genotype and their interaction with sperm quality traits in Chinese Holstein bulls are shown in Tables 3 and 4. Results of GLM analysis of variance showed that age had a significant effect on both FSM $(\mathrm{P}<0.01)$ and ASR $(\mathrm{P}<0.05)$. With regard to genotype, $B M P-15$ at the C5697T locus had a significant effect on FSM $(\mathrm{P}<0.05)$. The results of least square analysis (Table 4) showed that bulls with the CT genotype had a significantly lower FSM than bulls with the CC or TT genotype $(\mathrm{P}<0.05)$. 
Table 3. Analysis of variance (F values) between different factors and sperm quality traits in 205 Chinese Holstein bulls.

\begin{tabular}{|c|c|c|c|c|c|c|c|}
\hline Locus & Factor & VOL (mL) & $\mathrm{SD}\left(\mathrm{x} 10^{8} / \mathrm{mL}\right)$ & FSM $(\%)$ & AIR $(\%)$ & ASR (\%) & TSM (\%) \\
\hline \multirow[t]{3}{*}{ C5697T } & Age & 0.11 & 2.40 & $44.77 * *$ & 1.88 & $5.08 *$ & 0.88 \\
\hline & Genotype & 0.78 & 0.40 & $7.39^{*}$ & 0.77 & 1.06 & 1.35 \\
\hline & Age-genotype & 0.23 & 0.30 & 1.13 & 0.29 & 3.88 & 0.36 \\
\hline
\end{tabular}

*Means with significant differences at the significant level of $\mathrm{P}<0.05, * *$ means with significant differences at the significant level of $\mathrm{P}<0.01$. VOL $=$ volume per ejaculate; $\mathrm{SD}=$ sperm density; FSM $=$ fresh sperm motility; AIR $=$ acrosome integrity rate; $\mathrm{ASR}=$ abnormal sperm rate; $\mathrm{TSM}=$ thawed sperm motility.

Table 4. Effects of $B M P-15$ and $G D F-9$ genotypes on sperm quality traits in 205 Chinese Holstein bulls.

\begin{tabular}{lcccccrr}
\hline Locus & Genotype & VOL $(\mathrm{mL})$ & SD $\left(\times 10^{8} / \mathrm{mL}\right)$ & FSM $(\%)$ & AIR $(\%)$ & ASR $(\%)$ & TSM $(\%)$ \\
\hline C5697T & CC & $6.15 \pm 0.21$ & $11.56 \pm 0.40$ & $79.38 \pm 1.18^{\mathrm{a}}$ & $45.81 \pm 0.59$ & $15.38 \pm 0.46$ & $39.44 \pm 0.49$ \\
& CT & $5.44 \pm 0.94$ & $12.75 \pm 1.78$ & $62.72 \pm 5.24^{\mathrm{b}}$ & $48.00 \pm 5.07$ & $20.00 \pm 3.92$ & $44.00 \pm 4.07$ \\
& TT & $6.38 \pm 0.17$ & $11.59 \pm 0.33$ & $77.74 \pm 0.96^{\mathrm{a}}$ & $46.32 \pm 0.50$ & $15.88 \pm 0.39$ & $40.36 \pm 0.45$ \\
\hline
\end{tabular}

Least square means \pm SE marked with different lowercase superscripts were significant different at $\mathrm{P}<0.05$. For abbreviations, see Table 3.

\section{DISCUSSION}

There are many factors that affect sperm quality traits. Among them, age is one of the most important factors. Significant effects of age on FSM and ASR were observed in the present study (Table 3), and similar results were also obtained in our previous study (Sun et al., 2012). Researchers have found that sperm competition levels are positively associated with multiple sperm quality traits (Rowe and Pruett-Jones, 2011). Bhakat et al. (2011) demonstrated that with age, ASR increased but, sperm motility decreased in bulls. Semen volume and sperm motility significantly decrease with age also in healthy men (Eskenazi et al., 2003).

Members of the $T G F$ superfamily play roles in cell proliferation, differentiation, migration, and apoptosis and are key regulators of growth and development of the gonads (Ruiz-Ortega et al., 2007). Previous researchers have found that a deficiency in TGF-1 causes perturbed functioning of the hypothalamic-pituitary-gonadal axis, such as inhibition of luteinizing hormone synthesis (Ingman and Robertson, 2009) and FSH actions (Otsuka et al., 2001), which leads to downstream effects on testosterone production in males and estrous cycle abnormalities and reduced oocyte developmental competence in females.

Expression of BMP-15 in testis has been studied in rat (Nicholls et al., 2009). GDF-9 is also expressed in adult cat (Zhao et al., 2011), mouse (Fitzpatrick et al., 1998), and alpaca (Guo et al., 2013) testis. It is well known that normal spermatogenesis is dependent on optimal functioning of Sertoli cells. $B M P-15$ exerts its biological effects by initially interacting with a type II receptor (BMPRII), which leads to the recruitment, phosphorylation and activation of $A L K 6$ (Moore et al., 2003). Previous researchers have found that BMP-15 receptors are expressed by Sertoli cells and round spermatids and $G D F-9$ can modulate key Sertoli cell functions (Nicholls et al., 2009). GDF-9 is essential for the transition from primary spermatocytes to round spermids via autocrine, and regulates the tight junction function between adjacent Sertoli cells via paracrine effects and is involved in regulating spermatogenesis (Guo et al., 2013). BMP-15 shares high homology with GDF-9 (Otsuka et al., 2011). Mutations of the 
GDF-9 gene have an effect on sperm quality traits (Yang et al., 2011). However, up to now, no studies have been conducted on the effect of $B M P-15$ in sperm quality traits of bulls.

In the present study, we first detected polymorphisms of the $B M P-15$ gene and further analyzed their relationship with sperm quality traits in Chinese Holstein bulls. Association analysis showed that bulls with the CT genotype had a significantly lower FSM than did bulls with the CC or TT genotype and that CT was the most unfavorable genotype for the sperm quality trait FSM (Table 4). In males, high levels of BMP-15 were detected in the testes, suggesting that it could potentially regulate testicular function. The results of the present study complemented and verified the finding of the previous studies. To our knowledge, this is the first report of a putative association between $B M P-15$ gene mutation and sperm quality traits in Chinese Holstein bulls. Although the polymorphism studied was located in an intron that did not directly alter any amino acid residue, it was close to the exon-intron junction, which is important for mRNA splicing (Krawczak et al., 2007) and which may be directly related to functional variation. Studies have shown that the SNPs in introns can affect phenotype, gene expression and consequently function. For example, the G3072A mutation has been identified in intron 3 of the pig IGF2 gene, and found to be significantly associated with muscle growth by regulating the expression of IGF2 mRNA in postnatal muscle (Van Laere et al., 2003). Thus, variations in BMP-15 sequences may have important regulatory roles and be directly related to functional variations, but further verification is needed.

The present study is the first to investigate the effect of $B M P-15$ gene polymorphisms on sperm quality traits in Chinese Holstein bulls. The results indicated that $B M P-15$ could be considered as potential markers for improving sperm quality in bulls.

\section{ACKNOWLEDGMENTS}

Research supported by the China Agriculture Research System (\#CARS-37-04B), the Special Fund for Agro-Scientific Research in the Public Interest (\#201003060) and the SinoUK Cooperation Key Program (\#S2010GR0947).

\section{REFERENCES}

Barzegari A, Atashpaz S, Ghabili K, Nemati Z, et al. (2010). Polymorphisms in GDF9 and BMP15 associated with fertility and ovulation rate in Moghani and Ghezel sheep in Iran. Reprod. Domest. Anim. 45: 666-669.

Bhakat M, Mohanty TK, Raina VS, Gupta AK, et al. (2011). Effect of age and season on semen quality parameters in Sahiwal bulls. Trop. Anim. Health Prod. 43: 1161-1168.

Dixit H, Rao LK, Padmalatha VV, Kanakavalli M, et al. (2006). Missense mutations in the BMP15 gene are associated with ovarian failure. Hum. Genet. 119: 408-415.

England GC, Phillips L and Freeman SL (2010). Heritability of semen characteristics in dogs. Theriogenology 74: 11361140.

Eskenazi B, Wyrobek AJ, Sloter E, Kidd SA, et al. (2003). The association of age and semen quality in healthy men. Hum. Reprod. 18: 447-454.

Fitzpatrick SL, Sindoni DM, Shughrue PJ, Lane MV, et al. (1998). Expression of growth differentiation factor-9 messenger ribonucleic acid in ovarian and nonovarian rodent and human tissues. Endocrinology 139: 2571-2578.

Galloway SM, McNatty KP, Cambridge LM, Laitinen MP, et al. (2000). Mutations in an oocyte-derived growth factor gene (BMP15) cause increased ovulation rate and infertility in a dosage-sensitive manner. Nat. Genet. 25: 279-283.

Guo QY, Gao ZZ, Zhao L, He JP, et al. (2013). Expression of growth differentiation factor 9 (GDF9), ALK5, and claudin-11 in adult alpaca testis. Acta Histochem. 115: 16-21.

Ingman WV and Robertson SA (2009). The essential roles of TGFB1 in reproduction. Cytokine Growth Factor Rev. 20: 233-239. 
Kovanci E, Rohozinski J, Simpson JL, Heard MJ, et al. (2007). Growth differentiating factor-9 mutations may be associated with premature ovarian failure. Fertil. Steril. 87: 143-146.

Krawczak M, Thomas NS, Hundrieser B, Mort M, et al. (2007). Single base-pair substitutions in exon-intron junctions of human genes: nature, distribution, and consequences for mRNA splicing. Hum. Mutat. 28: 150-158.

Laissue P, Christin-Maitre S, Touraine P, Kuttenn F, et al. (2006). Mutations and sequence variants in GDF9 and BMP15 in patients with premature ovarian failure. Eur. J. Endocrinol. 154: 739-744.

Moore RK, Otsuka F and Shimasaki S (2003). Molecular basis of bone morphogenetic protein-15 signaling in granulosa cells. J. Biol. Chem. 278: 304-310.

Nicholls PK, Harrison CA, Gilchrist RB, Farnworth PG, et al. (2009). Growth differentiation factor 9 is a germ cell regulator of Sertoli cell function. Endocrinology 150: 2481-2490.

Nicol L, Bishop SC, Pong-Wong R, Bendixen C, et al. (2009). Homozygosity for a single base-pair mutation in the oocytespecific GDF9 gene results in sterility in Thoka sheep. Reproduction 138: 921-933.

Otsuka F, Yamamoto S, Erickson GF and Shimasaki S (2001). Bone morphogenetic protein-15 inhibits follicle-stimulating hormone (FSH) action by suppressing FSH receptor expression. J. Biol. Chem. 276: 11387-11392.

Otsuka F, McTavish KJ and Shimasaki S (2011). Integral role of GDF-9 and BMP-15 in ovarian function. Mol. Reprod. Dev. 78: 9-21.

Rowe M and Pruett-Jones S (2011). Sperm competition selects for sperm quantity and quality in the Australian Maluridae. PLoS One 6: e15720.

Ruiz-Ortega M, Rodriguez-Vita J, Sanchez-Lopez E, Carvajal G, et al. (2007). TGF- $\beta$ signaling in vascular fibrosis. Cardiovasc. Res. 74: 196-206.

Sang L, Du QZ, Yang WC, Tang KQ, et al. (2011). Polymorphisms in follicle stimulation hormone receptor, inhibin alpha, inhibin beta A, and prolactin genes, and their association with sperm quality in Chinese Holstein bulls. Anim. Reprod. Sci. 126: 151-156.

Sun LP, Du QZ, Song YP, Yu JN, et al. (2012). Polymorphisms in luteinizing hormone receptor and hypothalamic gonadotropin-releasing hormone genes and their effects on sperm quality traits in Chinese Holstein bulls. Mol. Biol. Rep. 39: 7117-7123.

Van Laere AS, Nguyen M, Braunschweig M, Nezer C, et al. (2003). A regulatory mutation in IGF2 causes a major QTL effect on muscle growth in the pig. Nature 425: 832-836.

Wolf J (2010). Heritabilities and genetic correlations for litter size and semen traits in Czech Large White and Landrace pigs. J. Anim. Sci. 88: 2893-2903.

Yan C, Wang P, DeMayo J, DeMayo FJ, et al. (2001). Synergistic roles of bone morphogenetic protein 15 and growth differentiation factor 9 in ovarian function. Mol. Endocrinol. 15: 854-866.

Yang WC, Tang KQ, Yu JN, Zhang CY, et al. (2011). Effects of MboII and BspMI polymorphisms in the gonadotropin releasing hormone receptor (GnRHR) gene on sperm quality in Holstein bulls. Mol. Biol. Rep. 38: 3411-3415.

Zhao L, He J, Guo Q, Wen X, et al. (2011). Expression of growth differentiation factor 9 (GDF9) and its receptor in adult cat testis. Acta Histochem. 113: 771-776. 